\title{
Sucção em recém-nascidos pré-termo e estimulação da $\operatorname{sucção***~}^{* *}$
}

\author{
Sucking in preterm newborns and the sucking stimulation
}

\begin{abstract}
Flávia Cristina Brisque Neiva*
Cléa Rodrigues Leone**
\end{abstract}

*Fonoaudióloga, Pós-Doutoranda na
Faculdade de Medicina da
Universidade de São Paulo. Endereço
de correspondência: Rua Paschoal
Guzzo, 530 - Jundiaí - SP -
CEP 13207-560
(flaviacbn@ yahoo.com.br).

**Médica Pediatra e Neonatologista. Professora Livre-docente e Associada do Departamento de Pediatria da Faculdade de Medicina da Universidade de São Paulo.

***Trabalho realizado no Berçário Anexo à Maternidade do Serviço de Pediatria Clínica, Intensiva e Neonatal - Instituto da Criança "Prof. Pedro de Alcântara", Hospital das Clínicas Faculdade de Medicina da

Universidade de São Paulo.

Artigo de Pesquisa

Artigo Submetido a Avaliação por Pares

Conflito de Interesse: não

Recebido em 11.08.2005.

Revisado em 08.09.2005; 14.03.2006; 17.04.2006.

Aceito para publicação em 26.06.2006.

\begin{abstract}
Background: non-nutritive sucking stimulation may anticipate the beginning of oral feeding and may influence the development of sucking in pre-term newborns. Aim: to describe the development of the sucking pattern and the effects of NNS. Method: participants of this study were 95 preterm newborns (PTNB), adequate for their gestational age (GA), born with GAs inferior or equal to 33 weeks, randomly distributed in three groups: Group 1 (G1) - control group - did not undergo NNS stimulation; Group 2 (G2) underwent NNS stimulation with orthodontic pacifier for premature infants; Group 3 (G3), underwent NNS stimulation with a gloved finger. All three groups of newborns underwent weekly NNS evaluations with a gloved finger and, after the beginning of the oral feeding (OF) they underwent NNS and nutritive sucking (NS) evaluations using a baby's mini milk bottle. Results: In all three groups, except for the stress signs in NNS and coordination between sucking- swallowing-breathing in NS, as the corrected gestational age (GA at birth plus postnatal age) increased, the occurrence probability of all studied sucking characteristics (NNS and NS) rose. In the NNS: sucking began easily (SBE) with no differences between the groups regarding rhythm, strength and coordination between lips, tongue and jaw; there was a higher probability of labial sealing, of tongue central groove formation and of tongue peristaltic movements in G3; stress signs were higher in G2 (>37 weeks). In the NS: SBE, coordination between lips, tongue and jaw, volume of ingested milk per total time did not show differences between the groups; rhythm and coordination between sucking, swallowing and breathing were higher in G3, labial sealing was higher in G1 and G3 $(<34$ weeks), and stress signs higher in G2 (> 33 weeks). Conclusion: the sucking pattern of PTNB developed due to the corrected gestational age, observing that NNS stimulation increased the occurrence probability of labial sealing, rhythm, tongue central groove formation, tongue peristaltic movements and coordination between sucking, swallowing and breathing. The gloved finger was the most effective instrument for NNS stimulation.
\end{abstract}

Key Words: Sucking Behavior, Newborn, Premature, Feeding Methods.

\section{Resumo}

Tema: a estimulação da sucção não-nutritiva pode antecipar o início da alimentação por via oral e influenciar a evolução da sucção em recém-nascidos pré-termo. Objetivo: descrever a evolução do padrão de sucção e os efeitos da estimulação da sucção não-nutritiva (SNN). Método: foram estudados 95 recémnascidos pré-termo (RNPT) adequados para a idade gestacional (IG), com IG ao nascer menor ou igual a 33 semanas, distribuídos de forma aleatória em três grupos: Grupo 1 (G1), grupo controle, sem estimulação da SNN; Grupo 2 (G2), com estimulação da SNN com chupeta ortodôntica para prematuros NUK® e Grupo 3 (G3), com estimulação da SNN através do dedo enluvado. Os três grupos foram submetidos a avaliação semanal da SNN com dedo enluvado e, após o início da alimentação por via oral (VO), avaliação da SNN e da sucção nutritiva (SN) com mini-mamadeira. Resultados: nos três grupos, com o aumento da IG corrigida, elevou-se a probabilidade de ocorrência de todas as características da sucção estudadas (SNN e SN), exceto sinais de estresse na SNN e coordenação sucção-deglutição-respiração na SN. Na SNN: sucção iniciada facilmente (SIF), ritmo, força e coordenação lábios, língua e mandíbula, sem diferenças entre os grupos; probabilidade maior de vedamento labial, acanolamento, peristaltismo no G3 e de sinais de estresse no G2 (> 37 semanas). Na suç̧ão nutritiva (SN): SIF, coordenação movimentos de lábioslíngua e mandíbula, volume de leite ingerido pelo tempo total sem diferenças entre os grupos; ritmo e coordenação sucção-deglutição-respiração superior no G3; vedamento labial superior nos G1 e 3 (<34 semanas) e sinais de estresse superior no G2 (> 33 semanas). Conclusão: o padrão de sucção de RNPT evoluiu em função da IG corrigida, tendo a estimulação da SNN aumentado a probabilidade de ocorrência de vedamento labial, ritmo, acanolamento, peristaltismo e coordenação sucção-deglutição-respiração, sendo o dedo enluvado a forma mais eficaz de estimulação da SNN.

Palavras-Chave: Comportamento de Sucção; Recém-Nascido; Prematuro; Métodos de Alimentação.

Referenciar este material como:

NEIVA, F. C. B.; LEONE, C. R. Sucking in preterm newborns and the sucking stimulation (original title: Sucção em recém-nascidos pré-termo e estimulação da suç̧ão). $\sum 3$ Pró-Fono Revista de Atualização Científica, Barueri (SP), v. 18, n. 2, p. 141-150, maio-ago. 2006. 


\section{Introduction}

The growth and the development of pre-term newborns (PTNB) have been a constant objective of the neonatal care to these newborns (NB), being nutrition one of the basic components (Silva et al, 2000; Facchini et al., 2000; Leone, 2002; Leone et al., 2002; Delgado \& Halpern, 2003).

In the first months of life, sucking constitutes the necessary function for efficient oral feeding and the adequate stomatognathic system development. For in such a way, it must be coordinated and harmonic and other factors are necessary to accomplish this function: rooting and sucking reflex, which leads to an easy beginning of sucking, labial sealing, adequate tongue and jaw movements, sucking rhythm, alternating sucking bursts with pauses, sucking, swallowing and breathing coordination (Morris \& Klein, 1987; Glass \& Wolf, 1994; Neiva, 2000a; Gamburgo et al., 2002; Hernandez, 2003a; Neiva et al., 2003; Neiva, 2003ab; Neiva, 2004; Bühler, 2003; Bühler \& Limongi, 2004a).

The PTNB has a global immaturity, including the stomatognathic system that increases the difficulty of execution of the sucking function and, consequently, the oral feeding (Neiva, 2000b; Hernandez, 2003a; Neiva, 2003c; Miller \& Kiatchoosakun, 2004; Bühler \& Limongi, 2004b).

Due to this, PTNB younger than 34 weeks routinely receive the food through an oral-gastric or naso-gastric tube, which abstains them from a serie of sensorial stimulations. The oral motor development may be affected because they do not perform sucking, and then a nutritive sucking disorganization may occur (Morris \& Klein, 1987, Hernandez, 2003b; Lau et al, 2003; Matias \& Melo, 2003). Thus, nonnutritive sucking stimulation (NNS) may minimize this sensorial deprivation and allow the PTNB to achieve total oral feeding at earlier age (Xavier, 2000; Fucile et al., 2002; Rocha et al., 2002; Rocha, 2002, Neiva, 2003abc, Caetano et al., 2003; Neiva, 2004).

The non nutritive sucking (NNS) stimulation may be performed with a pacifier (Sehgal et al., 1990), a gloved finger (Lindner, 1991; Oddy \& Glenn, 2003) and, according to Narayanan et al. (1991) with an empty maternal breast as well. Usually, the NNS is stimulated concomitantly to the enteral feeding when NB still does not receive the oral diet, providing: a maturation speed of sucking reflex and an intestinal transition stimulation, besides allowing the NB to associate sucking to gastric plenitude (Pinelli \& Symington, 2000).

The present study aims at describing the sucking pattern evolution and the effects of nonnutritive sucking stimulation (NNS) in adequate for gestational age (AGA) PTNB in relation to the corrected gestational age evolution, considering that NNS and nutritive sucking (NS) patterns change according to the maturation of this function along time, and that NNS stimulation may contribute for a faster maturation of NS, and can be influenced by the stimulation method used.

\section{Method}

The study was approved by The Ethics Committee for Research Projects Analysis -CAPPesq, Board of Hospital das Clínicas, School of Medicine, University of São Paulo (Number protocol: 370/01, date: 09-08-2001). Informed consent was signed by the parents or the ones in charge.

95 PTNB born at the Nursery Annex to the Maternity, Intensive and Neonatal Pediatrics Service - Instituto da Criança - Hospital das Clinicas - School of Medicine, University of São Paulo (FMUSP), were studied during the period from April 2000 until January 2002.

At the start of the study, the NB were clinically stable (without respiratory support, with hemodynamic stability and no apnea events) and received an exclusive enteral feeding by a gastric tube, or a combination of enteral and parenteral feedings (glucose solution, parenteral nutrition). NB with neurological disturbances, genetic syndromes, oral motor and/or congenital malformations were excluded.

$95 \mathrm{NB}$ were distributed in a random manner to ensure a balanced distribution of GA at birth and the corrected gestational age (GA at birth plus postnatal age) in the 3 groups of the study. Group 1, control group, was composed by 35 PTNB AGA who did not receive NNS stimulation. Group 2, was composed by 30 PTNB AGA who received NNS stimulation through an orthodontic pacifier NUK® for premature infants. Group 3, was formed by 30 PTNB AGA who received NNS stimulation with a gloved finger.

\section{Sucking evaluation}

During the period of the study, sucking evaluations (NNS and NS) were filmed in a standardized manner and weekly performed by the responsible researcher, close to the feeding time. Before starting the oral feeding, only the NNS evaluation was done, and at the beginning of the oral feeding, the NS evaluation was added. Except for the first NNS evaluation, that was done as soon as the NB fulfilled the inclusion criteria for the study, the evaluations were performed every week until the hospital discharge, in the following corrected gestational age: 28, 29, 30, 31, 32, $33,34,35,36,37,38,39$ and 40 weeks, with a variety of approximately 2 days.

It should be noted that the first NS evaluation 
corresponded to the first feeding of the NB through oral feeding. This evaluation always occurred when the NB presented clinical stability (respiratory support absence and receiving enteral diet), and elevation and lowering jaw movements, sucking rhythm, strength, and labial, tongue and jaw movement coordination in NNS, independently of the corrected gestational age. At the moment of the first NS evaluation, the NB used an oral gastric tube, and in the beginning of the transition they started receiving part of the milk through an oral gastric tube and, the other part through oral feeding with the bottle milk.

NNS evaluation was performed with the little gloved finger of the researcher's right hand during 6 minutes. In case that the NB one was receiving the oral feeding, after ten minutes of the NNS evaluation, NS evaluation was performed concomitant to one of the NB's feeding during 6 minutes or until the prescribed volume through oral feeding ended.

Both evaluations were performed when the NB was ready for sucking and in an adequate behavior, not being deeply asleep and not showing stress signs (crying, hiccups, chocking and others).

The characteristics observed in NNS and NS evaluation, were:

. easy beginning of sucking (EBS): considered present when NB, after being touched around their mouth by a gloved finger, they presented the rooting and/or sucking reflex, starting sucking;

. labial sealing: a seal around the gloved finger or the nipple of the bottle feeding;

. sucking rhythm: alternating sucking bursts with pauses;

. elevation and lowering jaw movement: opening and closing mouth movement;

. labial, tongue and jaw movement coordination: harmonious and integrated movement between these structures.

. stress signs: in NNS, crying, nausea and/or a change in the breathing rhythm, in NS, spilling of milk through oral cavity, choking and hiccups.

The characteristics observed only in NNS evaluation, were:

. tongue central groove: tongue pressure on the gloved finger against the palate and a contact between the lateral edges of the tongue and the palate;

- peristaltic tongue movements: contact between the soft palate and the back part of the tongue;

. sucking strength: tongue makes a pressure against the finger and the palate, with the resistance of the $\mathrm{NB}$ when the finger was removed.
Characteristics observed only in NS evaluation: . sucking, swallowing and breathing coordination: an equilibrium between the efficiency of the feeding and sucking, swallowing and breathing functions, without stress signs;

. milk volume ingested in total time: corresponded to the relation between ingested volume $(\mathrm{ml})$ and the time spend by the NB to swallow the milk (seconds).

These characteristics were observed during the entire NNS and NS evaluation, and the characteristic was considered present if it was predominant during all the day evaluations (a minimum of $75 \%$ presence in the total evaluation time), except for the stress signs item, which was registered even if the NB showed them only once.

All evaluations were filmed with a JVC GR SXM $321 \circledR$, using JVC VHS-C $®$ tapes. Than, the evaluations recorded were analyzed by the same researcher that performed the evaluations (the first author) in order to confirm the results obtained in the NNS and NS evaluation.

\section{NNS stimulation}

The NNS stimulation was executed every day just in Groups 2 and 3, except on weekends, during 10 minutes and concomitant to the feeding through an oral gastric tube during the milk feedings from 9:00, 12:00 and 3:00(pm), until the start of the oral feeding.

\section{Statistical analysis}

To certify the presence of differences among the groups in the characteristics at birth and at the moment of the study, a variance analysis was performed. For the observed variables in NNS evaluation, at the start of the study; the Chi-square test was used. In the evolution analysis of the present characteristics in NNS and NS, in different corrected gestational age, as well as the differences among the 3 groups of the studied PTNB, logistic regression models with repeated measures were used.

The significance level of $5 \%(\mathrm{p}<0.05)$ was used to specify the decisions based on statistical analysis. The software used for the analysis was: Excel for Windows (version 2000); Minitab for Windows (version 13); SAS V8.

\section{Results}

According to the study group, the NB's characteristics are shown in Table 01. No statistical differences were found among the groups in relation 
to any characteristics at birth and at the moment of the study ( $\mathrm{p}>0.05)$.

All NB were submitted to a NNS evaluation with a gloved finger concomitant to one of the feedings through an oral-gastric tube at the start of the study. Statistical differences were not detected among the 3 groups regarding the evaluated characteristics in this first evaluation ( $\mathrm{p}>0.05)$.

The evolution of each characteristic in NNS and NS evaluations, at the different corrected gestational age as well as the different manners of NNS stimulation are represented in Figures 1 to 3 . The results of the adjustment of the logistic regression model with repeated measures for these characteristics may be seen in Tables 2, 3 and 4.

In general, an increase of the probability in the occurrence of these variables was verified due to the advance of the corrected gestational age: easy beginning of sucking (EBS); labial sealing; sucking rhythm; stress signs; labial, tongue and jaw coordination (Figure 01); tongue central groove; peristaltic tongue movements; sucking strength (Figure 02); milk volume ingested in total time (Figure 03). In sucking, swallowing and breathing coordination, the occurrence probability was persistent for the 3 Groups, independent of the advance of the corrected gestational age (Figure 03).

It was observed too that the occurrence probability of easy beginning of sucking; labial sealing; sucking rhythm; stress signs; labial, tongue and jaw coordination was not different among the three groups of study. Regarding tongue central groove and peristaltic tongue movement occurrence probability was higher in the NB of Group 3 for the entire studied GA.

\section{TABLE 01: NB CHARACTERISTICS}

\begin{tabular}{|c|c|c|c|c|}
\hline Characteristics & $\begin{array}{c}\text { Group } 1 \\
(n=35)\end{array}$ & $\begin{array}{c}\text { Group } 2 \\
(n=30)\end{array}$ & $\begin{array}{c}\text { Group } 3 \\
(n=30)\end{array}$ & $\begin{array}{l}\text { Total } \\
n=95\end{array}$ \\
\hline \multicolumn{5}{|l|}{ At birth } \\
\hline GA at birth (weeks)* & $30,2($ SD 1,82$)$ & $30,6(\mathrm{SD} 1,45)$ & $30,6(\mathrm{SD} 1,40)$ & $30,5($ SD 1,57) \\
\hline Birth weight (grams)* & $1.389,1(\mathrm{SD} 404,7)$ & $1.357,4(\mathrm{SD} 324,2)$ & $1.425,3(\mathrm{SD} 298,4)$ & $1.389,8(\mathrm{SD} 346,4)$ \\
\hline Gender Male/female & $15 / 20$ & $17 / 13$ & $15 / 15$ & $47 / 48$ \\
\hline Delivery Cesarean/vaginal & $22 / 13$ & $20 / 8$ & $22 / 7$ & $64 / 28$ \\
\hline Apgar $1^{\prime} \quad<6 / \geq 6$ & $13 / 22$ & $15 / 14$ & $11 / 18$ & $39 / 54$ \\
\hline \multicolumn{5}{|l|}{ At the start of the study } \\
\hline Corrected gestational age (weeks)* & $31,4(\mathrm{SD} 1,5)$ & $31,7(\mathrm{SD} 1,2)$ & $31,7(\mathrm{SD} 1,3)$ & $31,6(\mathrm{SD} 1,3)$ \\
\hline Postnatal age (days) $*$ & $8,48(\mathrm{SD} 7,6)$ & $8,10(\mathrm{SD} 6,5)$ & $7,60(\mathrm{SD} 6,1)$ & $8,10(\mathrm{SD} 6,7)$ \\
\hline Weight (grams) * & $1.283(\mathrm{SD} 372,2)$ & $1.294(\mathrm{SD} 338,5)$ & $1.330(\mathrm{SD} 305,4)$ & $1.302(\mathrm{SD} 338,6)$ \\
\hline $\begin{array}{l}\text { Daily energetic offering } \\
\text { (Kcal/Kg)* }\end{array}$ & $45,58(\mathrm{SD} 34,4)$ & $44,74(\mathrm{SD} 29,4)$ & $45,31(\mathrm{SD} 34,3)$ & $45,23(\mathrm{SD} 32,5)$ \\
\hline Daily enteral volume $(\mathrm{ml} / \mathrm{Kg})^{*}$ & $63,63(\mathrm{SD} 46,3)$ & $66,70(\mathrm{SD} 43,9)$ & $63,81(\mathrm{SD} 46,3)$ & $64,66(\mathrm{SD} 45,1)$ \\
\hline
\end{tabular}

* mean/Standard deviations 
TABLE 02 - Results of the adjustments of logistic regression model with repeated measures for the common characteristics in NNS and NS evaluation

\begin{tabular}{llccc}
\hline Characteristics & Effect & Estimate & SD & p-value \\
\hline \multirow{3}{*}{ EBS } & Intercept & $-14,691$ & 2,108 & $<0,001$ \\
& IGCORR & 0,436 & 0,062 & $<0,001$ \\
& SN & 0,964 & 0,153 & $<0,001$ \\
\hline & Intercept & $-31,891$ & 5,541 & $<0,001$ \\
& DED & 29,200 & 7,626 & $<0,001$ \\
& CHU & 16,132 & 7,516 & 0,032 \\
Labial sealing & IGCORR & 1,033 & 0,174 & $<0,001$ \\
& SN & 36,683 & 9,441 & 0,000 \\
& DED*IGCORR & $-0,891$ & 0,235 & 0,000 \\
& CHU*IGCORR & $-0,495$ & 0,236 & 0,036 \\
& IGCORR*SN & $-1,101$ & 0,281 & $<0,001$ \\
& DED*SN & $-23,613$ & 10,458 & 0,024 \\
& CHU*SN & $-37,593$ & 11,474 & 0,001 \\
Sucking rhythm & DED*IGCORR*SN & 0,749 & 0,309 & 0,015 \\
& CHU*IGCORR*SN & 1,144 & 0,344 & 0,001 \\
\hline \multirow{2}{*}{ Labial, tongue and jaw coordination } & Intercept & $-18,710$ & 2,756 & $<0,001$ \\
& IGCORR & 0,600 & 0,083 & $<0,001$ \\
& DED*IGCORR*SN & 0,030 & 0,014 & $<0,001$ \\
\hline & Intercept & $-19,413$ & 2,976 & $<0,001$ \\
& IGCORR & 0,604 & 0,089 & $<0,001$ \\
& SN & 0,841 & 0,230 & $<0,001$ \\
\hline
\end{tabular}

TABLE 03 - Results of adjustments of logistic regression model with repeated measures for exclusive characteristics in NNS evaluation

\begin{tabular}{llccc}
\hline Characteristics & Effect & Estimate & SD & p-value \\
\hline \multirow{2}{*}{ Tongue central } & Intercept & $-14,286$ & 2,205 & $<0,001$ \\
groove & DED & 0,665 & 0,267 & 0,013 \\
Peristaltic tongue & IGCORR & 0,411 & 0,065 & $<0,001$ \\
\hline movements & DED & $-15,060$ & 2,131 & $<0,001$ \\
& IGCORR & 0,597 & 0,274 & 0,029 \\
Sucking strength & Intercept & 0,439 & 0,064 & $<0,001$ \\
& IGCORR & $-20,268$ & 3,119 & $<0,001$ \\
& & 0,628 & 0,094 & $<0,001$ \\
\hline
\end{tabular}


TABLE 04 - Results of adjustments of logistic regression model with repeated measures for exclusive characteristics in NS evaluation

\begin{tabular}{llccc}
\hline Characteristics & Effect & Estimate & SD & p-value \\
\hline \multirow{2}{*}{$\begin{array}{l}\text { Sucking, swallowing and } \\
\text { breathing coordination }\end{array}$} & Intercept & 1,249 & 0,237 & $<0,001$ \\
& DED & 1,247 & 0,389 & 0,001 \\
& CHU & 0,945 & 0,419 & 0,024 \\
\hline Volume/totaltime & Intercept & $-20,268$ & 3,119 & $<0,001$ \\
$(\mathbf{m l} /$ seg) & IGCORR & 0,628 & 0,094 & $<0,001$ \\
\hline
\end{tabular}

\footnotetext{
Abbreviation:

- Effect: $\quad$ stimulation and/or age and/or evaluation interfere in the variable mean.

- Intercept: $\quad$ Intercept or constant correspond to Covariance Analysis mean.

Correspond to variable value when the covariance zero. When p-values

$<0.001$ means that the intercept is different from zero and, when it is $>0.001$ means that it may be zero;

therefore it may be excluded form the model

- CGA: $\quad$ corrected gestational age effect

- PAC: $\quad$ NNS stimulation effect with pacifier

- FING NNS stimulation effect with finger

- NS: $\quad$ NS and NNS evaluation effect

- CGA*NS: $\quad$ corrected gestational age effect and in NS and NNS evaluation.

- FING*CGA: $\quad$ NNS stimulation effect with a finger and the corrected gestational age in group 3.

- PAC*CGA: $\quad$ NNS stimulation effect with pacifier and corrected gestational age in group 2

- FING*NS: $\quad$ NNS stimulation effect with a finger and NS evaluation.

- PAC*NS: $\quad$ NNS stimulation effect with pacifier and NS evaluation.

- FINGCGA*NS: NNS stimulation effect with a finger, corrected gestational age in group 3 and the NS evaluation.

- PAC*CGA*NS: NNS stimulation effect with pacifier, corrected gestational age in group 2 and NS evaluation.
} 
FIGURE 01 - Adjustment of the Logistic Regression with repeated measures for studied variable in NNS and NS
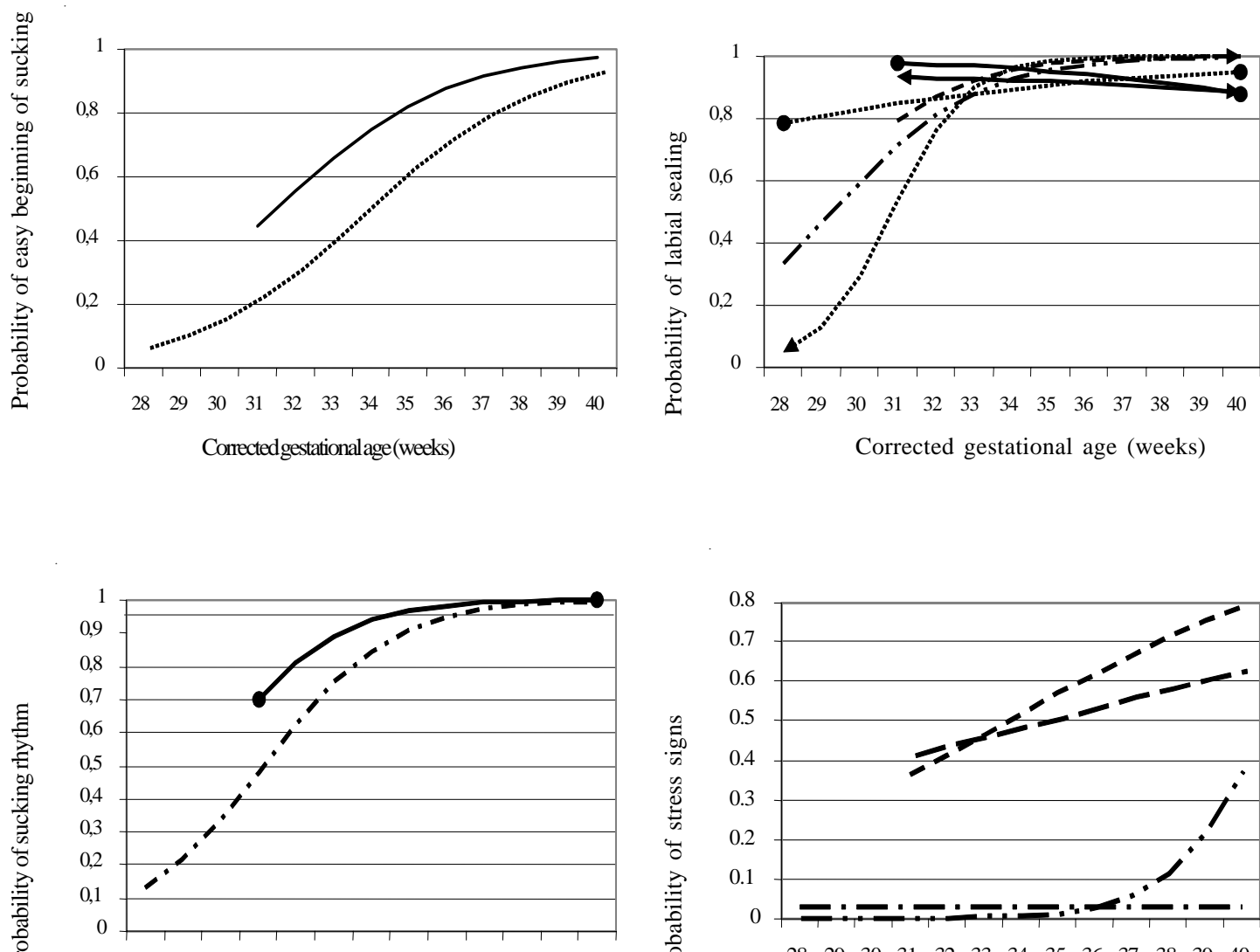

$\begin{array}{lllllllllllll}28 & 29 & 30 & 31 & 32 & 33 & 34 & 35 & 36 & 37 & 38 & 39 & 40\end{array}$

Corrected gestationalage(weeks)
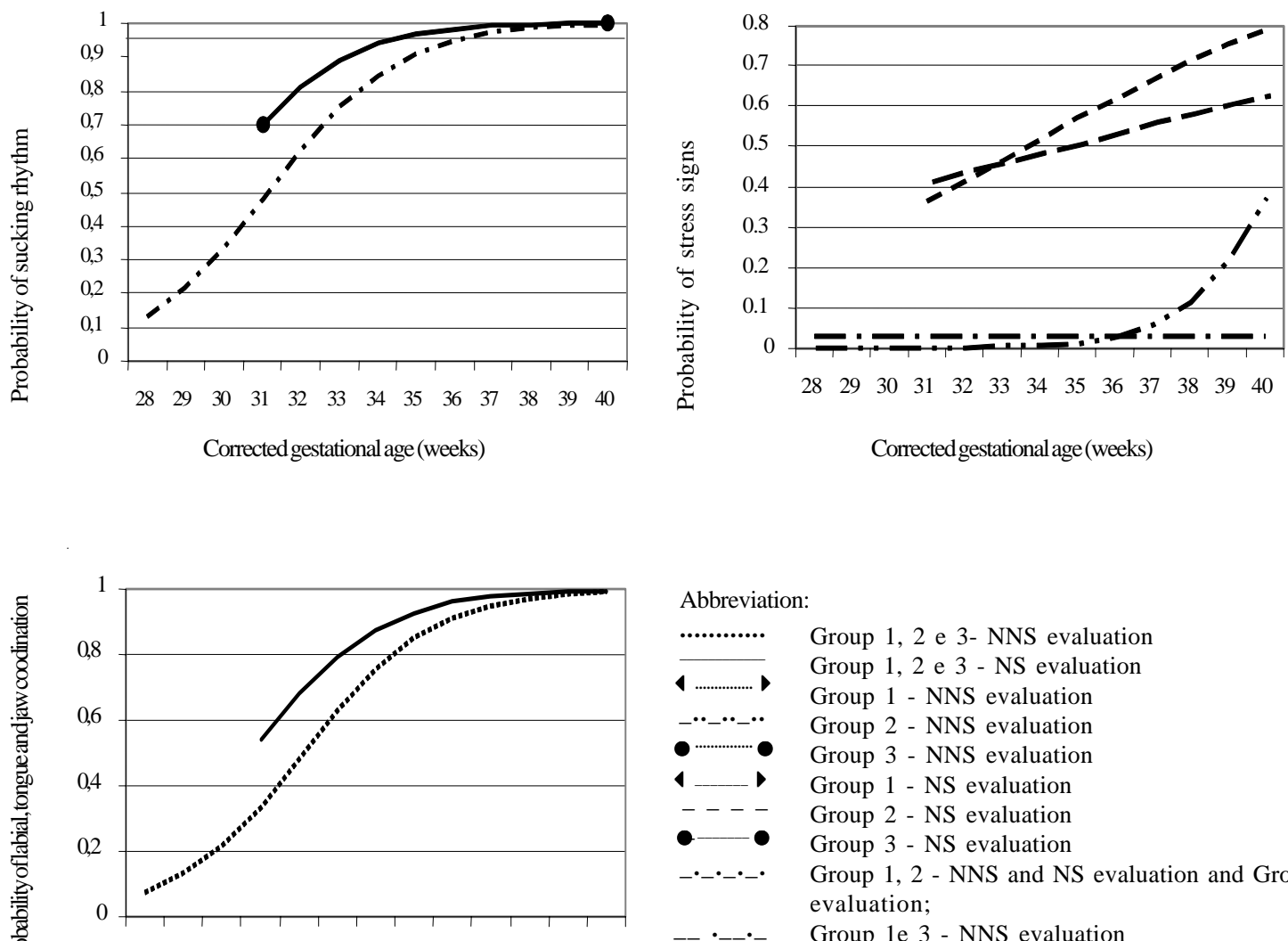

Abbreviation:

Group 1, 2 e 3-..... NNS evaluation

Group 1,2 e 3 - NS evaluation

Group 1 - NNS evaluation

-*_*-・ Group 2 - NNS evaluation

- Groun 3 - NNS evalu.... - Groution

4 Group 1 - NS evaluation

- - - Group 2 - NS evaluation

- Group 3 - NS evaluation

-••-••• Group 1, 2 - NNS and NS evaluation and Group 3 - NNS evaluation;

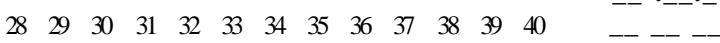

Group 1e 3 - NNS evaluation

Corrected gestational age (weeks) 
FIGURE 02 - Adjustment of the Logistic Regression Model with repeated measures for studied variable in NNS

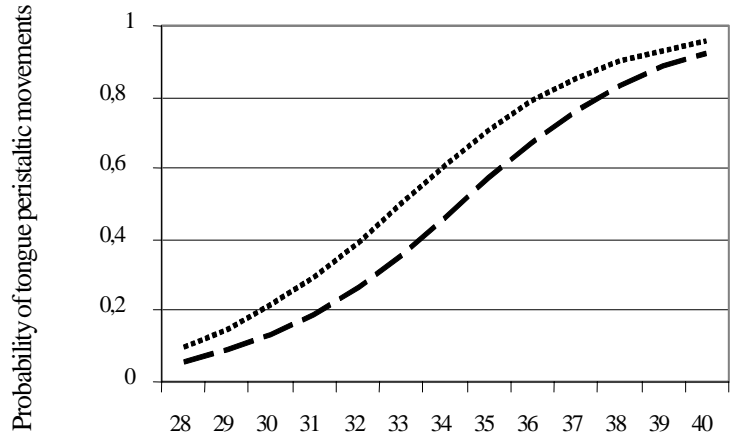

Corrected gestational age (weeks)
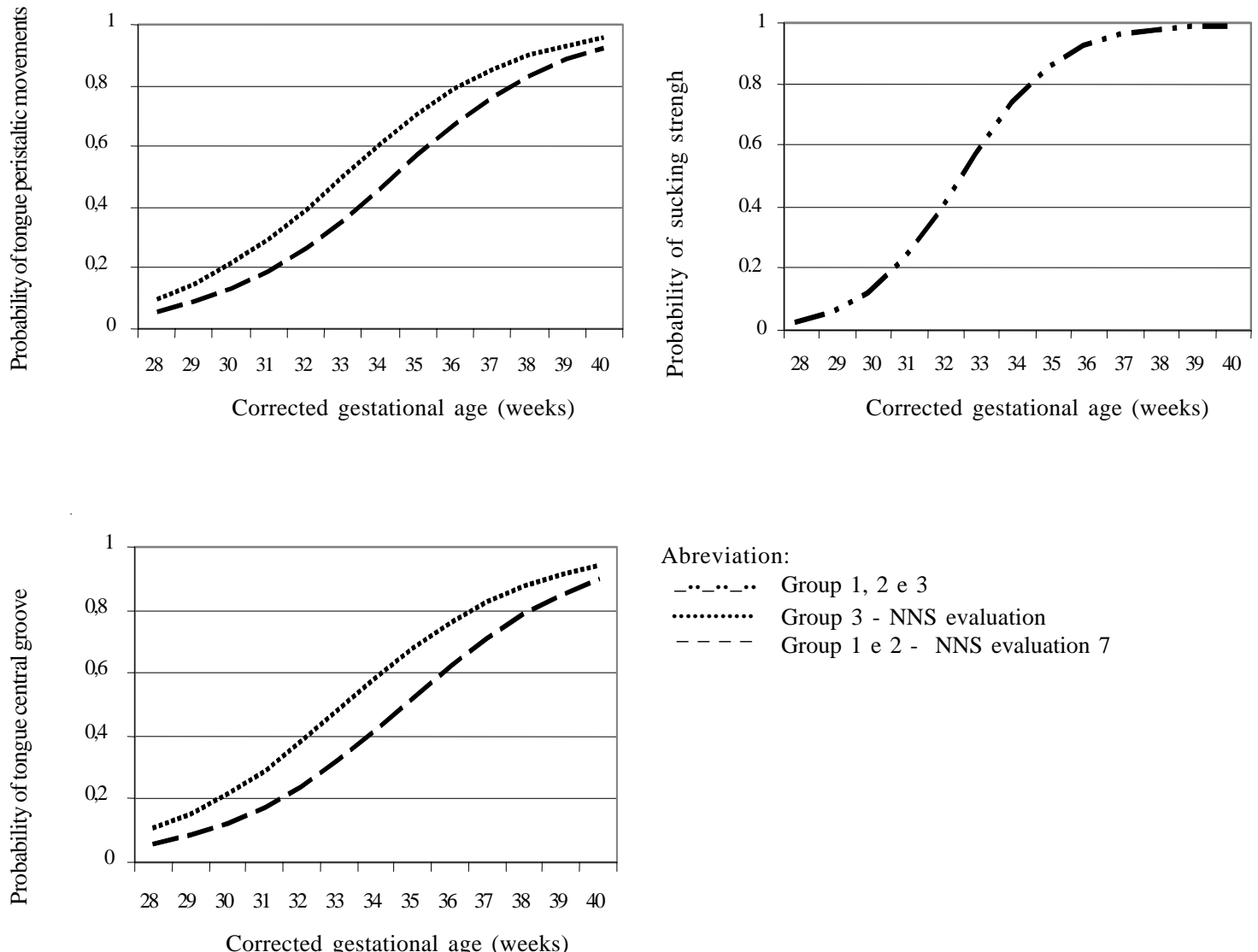

Abreviation:

-...*_.• Group 1,2 e 3

............ Group 3 - NNS evaluation

--- Group 1 e 2 - NNS evaluation 7

FIGURE 03 - Adjustment of the Logistic Regression Model with repeated measures for studied variable in NS
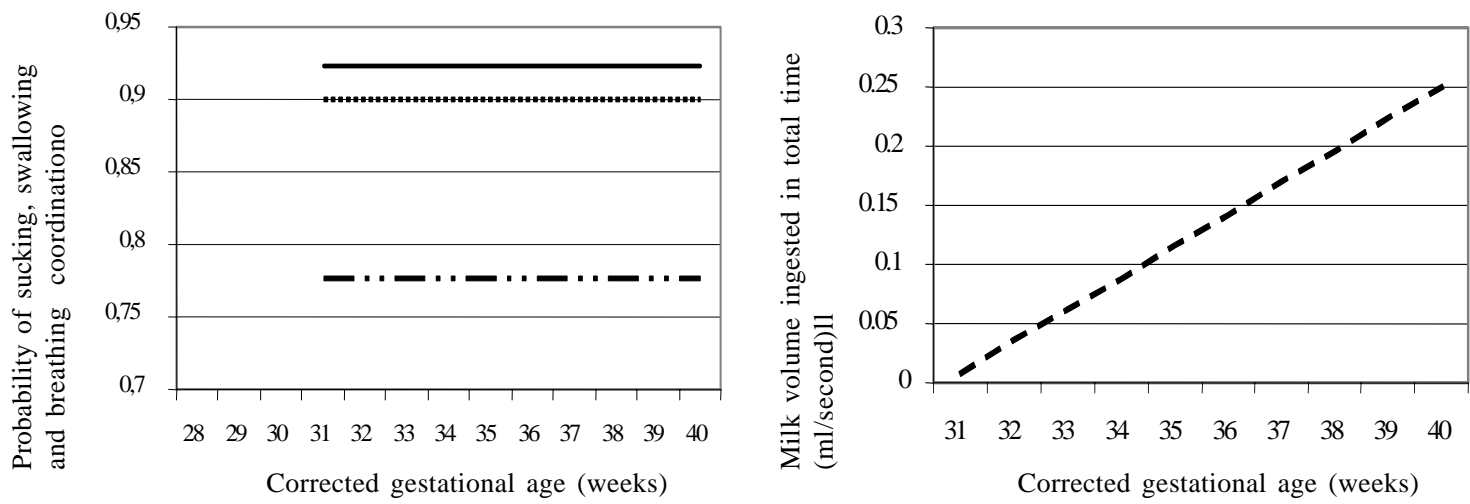

Abbreviation:

-.•_.... Group 1 - NS evaluation

........... Group 2 - NS evaluation

Group 3 - NS evaluation

Group 1, 2 e 3 


\section{Discussion}

Reports in the literature points out that the sucking skill modifies over time in pre-term NB, following the process of maturation of this function, improving itself with the increase of the GA of the NB (Morris \& Klein, 1987; Lau et al., 2000; Neiva, 2004). Iwayama and Eishima (1995) verified that PTNB with a gestational age of less than 30 weeks, showed a lower rate and quality of certain sucking components: easy beginning of sucking, labial sealing, tongue peristaltic movements and sucking rhythm. Moreover, Neiva (1999) and Lau et al. (2000) assure that with the advance of GA, there is an increase of the milk volume ingested due to a more efficient sucking and a better sucking rhythm adequacy, as it was verified in this study.

Such aspects were confirmed by the present study in the NS and NS common characteristics (easy beginning of sucking, labial sealing, sucking rhythm, stress signs and labial, tongue and jaw movement coordination), in the exclusive characteristics of the NNS (tongue central groove and tongue peristaltic movements and sucking strength) and of the NS (ingested milk volume in total time). On these, an elevation of the occurrence probability as there was a corrected gestational age increase has been verified, except for the stress signs which were persistent for G1 and G3 in NNS and, in the variable sucking, swallowing and breathing coordination in NS, persistent for the 3 groups.

In relation to stress signs, these are often observed in the PTNB sucking pattern (Morris \& Klein, 1987; Thoyre \& Carlson, 2003), and therefore they should be reduced with the NB's GA increase, once these ones become older and able to suck without stressing themselves. In this study, an increase in the occurrence probability of stress signs, with an increase of the GA, was observed in the NS evaluation, and this may be related to the fact that an increase in the milk volume was prescribed each subsequent day, according to Neonatal Unit rules. Therefore, after starting the oral feeding, the administered milk volume was daily increased. Thus, even though they are older, they need to ingest a larger milk volume each feeding, which may mean a greater strength for some NB and the unleashing of these stress signs.

Regarding the NNS stimulation effects, some studies show that NNS stimulation speeds up the sucking maturation, improving the pattern (Sehgal et al., 1990; Pinelli \& Symington, 2000, Mc Cain, 2003). On the other hand, these studies do not mention in detail and separately which sucking characteristics are beneficiated.

NNS stimulation effect was not verified in some sucking characteristics: easy beginning of sucking, and labial, tongue and jaw movements coordination, sucking rhythm, sucking strength, milk volume ingested in total time, showing that the probability for these ones was the same for all the 3 groups of studied NB.

Otherwise, some authors (DeCurtis et al., 1986 and Goldson, 1987) consider that NNS stimulation speeds up the maturation of the sucking reflex. The different results obtained in this study could be a consequence of the insufficient number of daily stimulations, as they were done in $37.5 \%$ of the NB feedings during the whole day.

In relation to other characteristics as: labial sealing, sucking rhythm, tongue central groove and peristaltic tongue movements, the stimulation of the NNS with the gloved finger was more efficient of the one than with the pacifier, therefore in this group (G3) it had an increase of the occurrence probability of these characteristics.

It is standed out that, in some characteristics (sucking rhythm in NS evaluation, tongue central groove and peristaltic tongue movements), the influence of the stimulation with pacifier has not been verified, and whose results have been similar to the ones of the control group. Although it is not a consensus the fact that the stimulation of NNS, depending on the type of used stimulus, can influence the evolution of the sucking maturation, the present study showed that this interference is positive, as it sped up the evolutive process of some components of sucking, confirming the hypotheses of this research.

The use of the gloved finger, besides having increased the occurrence probability of some characteristics of sucking in relation to pacifier, also has the advantage to require the obligatory presence of the person who carries through this stimulation to the NB during this procedure, being able this to carry through a more rigorous comment of its reply to the stimulation. 


\section{Conclusion}

Concluding, the findings of this study show that the maturation process for the capacity of sucking has evolved with the corrected gestational age increase and the passage of time. This velocity may be related to the pathological limitans, as the intercurrences after birth and environmental interferences, represented by NNS stimulation and the type of offered stimulus, being the gloved finger the most adequate stimulus.
Therefore, aiming at reinforcing the PTNB sucking in more precocious phases, NNS stimulation performance with a gloved finger is recommended as an adequate and efficient instrument.

Thanks: Fundação de Amparo à Pesquisa do Estado de São Paulo (FAPESP).

\section{References}

BÜHLER, K. E. C. B. Introdução da alimentação via oral com o uso do copinho em recém-nascidos pré-termo: critérios fonoaudiológicos. 2003. 140 f. Dissertação (Mestrado em Ciências) - Faculdade de Medicina, Universidade de São Paulo, São Paulo.

BÜHLER, K. E. B.; LIMONGI, S. C. O. O uso do copinho como método de alimentação de recém-nascidos pré-termo: revisão de literatura. R. Soc. Bras. Fonoaudiol., São Paulo v. 9, n. 2, p. 115-121, abr.-jun. 2004a.

BÜHLER, K. E. B.; LIMONGI, S. C. O. Fatores associados à transição da alimentação via oral em recém-nascidos prétermo. Pró-Fono R. Atual. Cient., Barueri (SP), v. 16, n. 3, p. 301-310, set.-dez. 2004b.

CAETANO, L. C.; FUJINAGA, C. I.; SCOCHI, C. G. S. Sucção não-nutritiva em bebês prematuros: estudo bibliográfico. $R$. Latino-am. Enferm., Ribeirão Preto, v. 11, n. 2, p. 232-236, março-abr. 2003.

DeCURTIS, M.; MCINTOSH, N.; VENTURA, B. S.; BROOKE, O. Effect of non nutritive sucking on nutrient retention in preterm infants. J. Pediatr., New York, v. 109, n. 5 , p. $888-890$, nov. 1986.

DELGADO, S. E.; HALPERN, R. Possibilidade de intervenção fonoaudiológica an facilitação do vínculo mãebebê, através do aleitamento materno. Pediatr. Mod., São Paulo, v. 39, n. 3, p. 53-57, março 2003.
FACCHINI, L. C.; ALMEIDA, S. T.; DELGADO, S. E. O perfil da demanda para intervenção fonoaudiológica na UTI neonatal do Hospital de Clínicas de Porto Alegre. Pró-Fono R. Atual. Cient., Carapicuíba (SP), v. 12, n. 1, p. 17-23, 2000. FUCILE, S.; GISEL, E.; LAU, C. Oral stimulation accelerates the transition form tube to oral feeding in preterm infants. J. Pediatr, St. Louis, v. 141, n. 2, p. 230-236, Aug. 2002.

GAMBURGO, L. J. L.; MUNHOZ, S. R. M.; AMSTALDEN, L. G. Alimentação do recém-nascido: aleitamento natural, mamadeira e copinho. Fono Atual, São Paulo, n. 20, p. 3947, $2^{\circ}$. trimestre. 2002.

GLASS, R. P.; WOLF, L. S. A global perspective on feeding assessment in the neonatal intensive care unit. Am. J. Occup. Ther., Bethesda, v. 48, n. 6, p. 514-526, june 1994.

GOLDSON, E. Nonnutritive sucking in the sick infant. $J$. Perinatol., Philadelphia, v. 7, n. 1, p. 30-34, winter 1987. HERNANDEZ, A. M. O neonato de alto risco: proposta de intervenção global. In: HERNANDEZ, A. M. Conhecimentos essenciais para atender bem o neonato. São Paulo: Pulso, 2003a . p. 15-23.

HERNANDEZ, A. M. Atuação fonoaudiológica com o sistema estomatognático e a função de alimentação. In: HERNANDEZ, A. M. Conhecimentos essenciais para atender bem o neonato. São Paulo: Pulso, 2003b. p. 4778 . 
IWAYAMA, K.; EISHIMA, M. Sucking behavior of normal full-term and low risk preterm. No To Hattatsu, Tokyo, v. 27 , n. 5, p. 363-369, sep. 1995.

LAU, C.; ALGURUSAMY, R.; SCHANLER, R. J.; SMITH, E. O.; SHULMAN, R. J. Characterization of the developmental stages of sucking in preterm infants during bottle feeding. Acta Paediatr., Oslo, v. 89, n. 7, p. 846852 , july 2000 .

LAU, C.; SMITH, E. O.; SCHANLER, R. J. Coordination of suck-swallow and swallow respiration in preterm infants. Acta Paediatric., Oslo, v. 92, n. 6, p. 721-727, june 2003.

LEONE, C. R. Técnicas de alimentação por via digestiva no recém-nascido de muito baixo peso. In: TRINDADE FILHO, O.; ALVES FILHO, N. Clínica de Perinatologia: Procedimentos e Técnicas em Neonatologia. Rio de Janeiro: MEAS Editora médica e Científica Ltda, 2002. p. 13-19.

LEONE, C. R.; RAMOS, J. A.; VAZ, F. A. O recém-nascido pré-termo. In: MARCONDES, E.; VAZ, F. A. C; RAMOS, J. L. A.; OKAY, Y. Pediatria Básica. 9. ed. São Paulo: Sarvier, 2002. p. 348-352.

LINDNER, A. Measurement of intra-oral negative ais pressure during dummy sucking in human newborn. Eur. J. Orthodontics, London, v. 13, n. 4, p. 317-321, aug. 1991.

MATIAS, E. L.; MELLO, D. F. O seguimento fonoaudiológico e a participação materna na assistência ao recém-nascido pré-termo e de baixo peso. $R$. Fonoaudiol. Brasil, Brasília, v. 2, n. 3, p. 60-64, jun. 2003.

MCCAIN, G. C. An evidence-based guideline for introducing oral feeding to healthy preterm infants. Neonatal Network - J. Neonatal Nurs., Santa Rosa, v. 22, n. 5, p. 45-50, Sep.Oct. 2003.

MILLER, M. J.; KIATCHOOSAKUN, P. Relationship between respiratory control and feeding in the developing infant. Seminars Neonatol., London, v. 9, n. 3, p. 221-227, Jun. 2004.

MORRIS, S.; KLEIN, M. Pre-feeding skills: a comprehensive resourse for feeding development, therapy skill builders. Arizona: Tucson, 1987.

NARAYANAN, I.; MEHTA, R.; CHOUDHURY, D. K.; JAIN, B. K. Sucking on the 'emptied' breast: non-nutritive sucking with a difference. Arch. Dis. Child., London, v. 66, n. 2, p. 241-244, feb. 1991.

NEIVA, F. C. B. Ritmo de sucção: variações na duração das eclosões e das pausas durante a sucção de recém-nascidos. In: SOCIEDADE BRASILEIRA DE FONOAUDIOLOGIA. Atualização em voz, linguagem, audição e motricidade oral. São Paulo: Frôntis Editorial, 1999, p. 435-449. (Coleção Sociedade Brasileira de Fonoaudiologia).

NEIVA, F. C. B. Proposta de um Formulário de Avaliação da Sucção de Recém Nascidos. Pró-Fono R. Atual. Cient., Carapicuíba (SP), v. 12, n. 2, p. 113-119, set. 2000a.

NEIVA, F. C. B. Sucção em recém-nascidos: algumas contribuições da fonoaudiologia. Pediatr., São Paulo, v. 22, n. 3 , p. $264-270,2000 b$.
NEIVA, F. C. B.; CATTONI, D. M.; RAMOS, J. L. A.; ISSLER, H. Desmame precoce: implicações para o desenvolvimento motor-oral. J. Pediatr., Porto Alegre, v. 79, n. 1, p. 7-12, jan.-fev. 2003

NEIVA, F. C. B. Aleitamento Materno em recém-nascidos. In: HERNANDEZ, A. M. Conhecimentos essenciais para atender bem o neonato. São Paulo: Pulso, 2003a. p. $97-$ 105

NEIVA, F. C. B. Amamentação do recém-nascido na unidade de cuidados intensivos: atuação fonoaudiológica. In: FERFEBAUM, R.; FALCÃO, M. C. Nutrição do Recémnascido. São Paulo: Atheneu, 2003b. p. 257-264.

NEIVA, F. C. B. Análise evolutiva do padrão de sucção e a influência da estimulação através da sucção nào-nutritiva em recém-nascidos pré-termo. 2003c. 181 f. Tese (Doutorado em Ciências) - Faculdade de Medicina, Universidade de São Paulo, São Paulo.

NEIVA, F. C. B. Neonatologia: papel do fonoaudiólogo no berçário. In: COMITÊ DE MOTRICIDADE ORAL: Sociedade Brasileira de Fonoaudiologia. Motricidade orofacial: como atuam os especialistas. São José dos Campos: Pulso, 2004, p. 225-234.

ODDY, W. H.; GLENN, K. Implementing the Baby Friendly Hospital Initiative: the role of finger feeding. Breastfeeding Review, Nunawading, v. 11, n. 1, p. 5-10, mar. 2003.

PINELLI, J.; SYMINGTON, A. Non-nutritive sucking for promoting physiologic stability and nutrition in preterm infants. Cochrane Database Syst. Rev., v. 4, oct. 2005. 2:Cd001071.

ROCHA, A. D; MOREIRA, M. E. L.; RAMOS, J. R. M.; COSTA, A. M.; MALLET, N. R. Efeitos da sucção não-nutritiva durante a alimentação enteral nos parâmetros temporais da sucção de neonatos pré-termo. J. Brás. Fonoaudiol., Curitiba, v. 3, n. 13, p. 298-303, out.-dez. 2002

ROCHA, A. D. Efeitos da sucção não-nutritiva durante a alimentação enteral em crianças prematuras. 2002. 122 f. Dissertação (Mestrado em Saúde da Criança e da Mulher) - Instituto Fernandes Figueira, Fundação Oswaldo Cruz, Rio de Janeiro.

SEHGAL, S. K.; PRAKASH, O.; GUPTA, A.; MOHAN, M.; ANAND, N. K. Evaluation of benefical effects of nonnutritive sucking in preterm infants. Indian Pediatr. New Delhi, v. 27, n. 3, p. 263-266, mar. 1990

SILVA, M. H. A.; SCOCHI, C. G. S.; KOKUDAY, M. L.; SPRIOLI, R. M.; NETTO, K. A. S. Alimentação do bebê prematuro e de muito baixo peso ao nascer: subsídios para a assistência de enfermagem em berçário. Pediatr. Mod., São Paulo, v. 36, n. 5, p. 282-295, maio 2000.

THOYRE, S. M.; CARLSON, JR. Preterm infants' behavioural indicators of oxygen decline during bottle feeding. J. Advanced Nurs., Oxford, v. 43, n. 6, p. 631641, sep. 2003.

XAVIER, C. Trabalho fonoaudiológico com bebês durante a fase hospitalar. In: LIMONGI, S. C. O. Paralisia cerebral: processo terapêutico em linguagem e cognição. Carapicuíba (SP): Pró-Fono, 2000. p.75-118 